Portland State University

PDXScholar

\title{
Radical, Reformist, and Garden-Variety Neoliberal: Coming to Terms with Urban Agriculture's Contradictions
}

Nathan McClintock

Portland State University, n.mcclintock@pdx.edu

Follow this and additional works at: https://pdxscholar.library.pdx.edu/usp_fac

Part of the Social Policy Commons, Urban Studies Commons, and the Urban Studies and Planning Commons

Let us know how access to this document benefits you.

\section{Citation Details}

McClintock, Nathan, "Radical, Reformist, and Garden-Variety Neoliberal: Coming to Terms with Urban Agriculture's Contradictions" (2014). Urban Studies and Planning Faculty Publications and Presentations. 93.

https://pdxscholar.library.pdx.edu/usp_fac/93

This Post-Print is brought to you for free and open access. It has been accepted for inclusion in Urban Studies and Planning Faculty Publications and Presentations by an authorized administrator of PDXScholar. Please contact us if we can make this document more accessible: pdxscholar@pdx.edu. 
Uncorrected post-print version

Published in Local Environment (2014), Vol. 19, No. 2, pp. 147-171.

\title{
Radical, reformist, and garden-variety neoliberal: coming to terms with urban agriculture's contradictions
}

Nathan McClintock

Toulan School of Urban Studies \& Planning, Portland State University, Portland, Oregon, USA

\begin{abstract}
For many activists and scholars, urban agriculture in the Global North has become synonymous with sustainable food systems, standing in opposition to the dominant industrial agri-food system. At the same time, critical social scientists increasingly argue that urban agriculture programs, by filling the void left by the "rolling back" of the social safety net, underwrite neoliberalization. I argue that such contradictions are central to urban agriculture. Drawing on existing literature and fieldwork in Oakland, California, I explain how urban agriculture arises from a protective counter-movement, while at the same time entrenching the neoliberal organization of contemporary urban political economies through its entanglement with multiple processes of neoliberalization. By focusing on one interpretation or the other, however, rather than understanding such contradictions as internal and inherent, we risk undermining urban agriculture's transformative potential. Coming to terms with its internal contradictions can help better position urban agriculture within a coordinated efforts for structural change, rather than promoting farming in cities as an end unto itself, one of many means to an end rather than an end unto itself.
\end{abstract}

Keywords: alternative food networks; community gardens; neoliberalism; Polanyi; urban agriculture; urban farming 


\section{Introduction}

A produce stand sits in front of a verdant urban garden established by City Slicker Farms, one of the dozen or so food justice projects practicing urban agriculture in Oakland, California. A price board is sub-divided into three columns with three different prices for each vegetable. The adjacent sign asks, "Which price level are you in today?" Level 1 reads: "Free Spirit: Your unemployment check hasn't come, or for whatever reason cash is not flowing in. Have some free veggies, no explanation needed." Level 2 follows: "Just Getting By: Money is tight and if it weren't for City Slicker Farms you'd be searching for deals at Safeway." And finally, Level 3: "Sugar Mama/Daddy: You may not be rolling in riches, but you can afford to shop at Whole Foods or the Berkeley Farmers Market. Pay a little more to help someone out. Thanks!"

This sliding scale food stand is representative of the approach that many food justiceoriented urban agriculture initiatives are taking. Such projects provide free and low-cost produce to local residents, a fresh and nutritious complement to the fast food and processed foods that dominate food retail in the city's low-income neighborhoods. Like other alternative food networks (AFNs) that have arisen over the last couple of decades in opposition to the dominant market logic and externalities of the industrial agri-food system (Allen et al. 2003, Maye et al. 2007, Jarosz 2008), this model of production and distribution is both interstitial and subversive. Urban gardens such as these arise within the interstices and margins of both the food system-by providing food where markets have failed — and of the built environment itself — arising on vacant lots and other urban fallow. Espousing a vision of equity and civic responsibility, projects such as these arise in an attempt to subvert the industrial agri-food system. Moreover, these projects attempt to subvert the commodity form itself, by viewing food as a public good, prioritizing its equitable distribution over profit. Indeed, according to the radical model embodied by City Slicker Farms and other urban agriculture organizations, people with privilege and wealth should subsidize the less fortunate.

Ironically, urban agriculture projects such as this serve as another type of subsidy: the subsidization of capital, or more specifically, of capitalist accumulation. Like other interstitial and subversive food spaces described in this issue, such alternative forms of food provisioning ultimately fill in gaps left by the rolling back of the social safety net. From this perspective, the burden of food production and provisioning of healthy food in low-income areas has largely shifted from the state to non-profits and community-based organizations operating in areas where market failure limits both wages and purchasing power.

Scholarship on urban agriculture has tended to emphasize one of these two analytical perspectives. At one end of the spectrum, scholars from a range of disciplines extoll urban agriculture's potential contributions to food security and food justice, public health, environmental sustainability, green jobs, education, and community-building, both echoing and creating discourse widely embraced by activists and other stakeholder publics. At the other end of the spectrum, a more critical camp of social scientists peels back this laudatory discourse to interrogate AFNs such as urban agriculture. They demonstrate how-often despite their progressive or radical intentions-AFNs are neoliberal in their outcomes, or reformist at best, in that they continue to work within the capitalist logic of the food system (Allen and Guthman 2006, Guthman 2008, Holt-Giménez and Wang 2011, Alkon and Mares 2012). While both the celebrations and critiques of urban agriculture are compelling, however, I argue that both perspectives are incomplete and tend to oversimplify urban agriculture's function by giving 
primacy to one interpretation over the other, often conflating the diverse rationalities driving urban agriculture's multiple forms in the process.

Clearly, we need a more sophisticated approach to understanding urban agriculture, where it comes from, and how to address its impact. If contestation and struggle over urban space is ultimately carried out through everyday practices (Loftus 2012) — practices that arise as a result of specific historical and geographical relationships - analysis of multiple scales, both spatial and temporal, should reveal that urban agriculture, in its many forms, is not radical or neoliberal, but may exemplify both a form of actually existing neoliberalism and a simultaneous radical countermovement arising in dialectical tension. Further, I contend that urban agriculture has to be both; indeed, contradictory processes of capitalism both create opportunities for urban agriculture and impose obstacles to its expansion. Identifying these contradictions requires analysis of urban agriculture's various forms and functions at multiple scales.

Throughout the paper, I draw on existing literature and my own fieldwork in Oakland, California, a city where food justice activists have cultivated a fast growing urban agriculture movement. ${ }^{1}$ In the next section I briefly present a typology of urban agriculture's diverse forms before. In Section 3 I present two different interpretations of urban agriculture, first summarizing existing arguments on the radical qualities of urban agriculture, notably its ability to re-embed the food system within social relations that have been effaced or appropriated by the dominant industrial agri-food system. I then review and build on existing critiques of urban agriculture's entanglement in various processes of neoliberalization, most notably the roll-out of non-profits to fill in the gaps left by the rolling back of the social safety net, and the promulgation of neoliberal discourses of personal responsibility and market-based solutions.

In Section 4 I attempt to make sense of these contradictory interpretations-both of which I believe are correct - and explain how the two seemingly divergent processes operate in an ongoing and co-productive manner. I first draw on Polanyi, emphasizing the dialectical nature of capitalism's double movement, then refine his framework by arguing that we must look beyond monolithic understandings of society and market to identify urban agriculture's contradictions. I then present urban agriculture as a spatial process requiring analysis at multiple scales before drawing on examples from Oakland to demonstrate how urban agriculture's integument within the broader political economy give rise to multiple meanings and contradictory functions.

I conclude the paper by arguing that for scholars and activists alike, coming to terms with urban agriculture's inherent contradictions is an important step towards a the reflexivity necessary for a "transformative food politics" (Levkoe 2011). Situating urban agriculture within a broader multiscalar framework of political economic structure can reveal these contradictory tendencies and moves scholarship beyond a potentially disabling dualism. It can also help to situate urban agriculture practice within wider agendas of structural change and "just sustainability" (Agyeman 2005, Alkon and Agyeman 2011) while helping to identify its limits and possibilities and limits. By positioning urban agriculture as only one of many synchronous and complementary means to an end rather than an end unto itself, we can be more realistic (and at the same time hopeful) about its possible contributions to food justice and social change.

\footnotetext{
${ }^{1}$ Research took the form of dozens of formal and informal interviews and participant observation while working with two urban agriculture organizations, a food justice collaborative, and a food policy council between 2008 and 2011.
} 


\section{Urban agriculture's diverse forms}

While a detailed discussion of urban agriculture's various forms lies outside the scope of this paper, it is important to differentiate them if we are to determine if and how urban agriculture can be at once neoliberal and radical. In Table 1 I present a rough typology of the most common forms of urban food production, with particular attention paid to the scale, function, labor and management, and integration into the market of each. I don't propose these as static categories. Instead, my intent is to parse out the diversity of relations between production, land, labor, and markets, that is, the multiple ways in which urban agriculture serves as a site of socio-ecological metabolism (Heynen 2006, McClintock 2010, Shillington 2012). As with any typology, not every example of urban agriculture maps neatly onto a single category. In some cases, there may be overlap; for example, a non-profit or institutional urban agriculture project may operate their garden as a collective rather than as an allotment, or a residential gardener may be involved in commercial marketing. Despite these inherent shortcomings, the typology reveals that urban agriculture operates at multiple scales, providing food for individuals and for communities of various sizes, both through and outside of traditional market mechanisms.

While it is difficult to quantify the scale of urban agriculture today, a patchwork of studies sheds some light on the extent to which urban residents produce their own food. The percent of the population engaged in urban food production is surprisingly high. One study found that 36 million households in the US (or roughly a third of all households) practiced food gardening in 2008 and the total was expected to increase to 43 million households the following year (National Gardening Association 2009). More than half of respondents (54\%) noted that they practice gardening to save money on groceries and a third (34\%) responded that the current economic recession motivated them "very much" or "a fair amount". A Canadian study of domestic food production came to similar conclusions: $40 \%$ of Toronto residents and $44 \%$ of Vancouver residents reported that someone in their household grew food (City Farmer 2002).

Scale of production can also be estimated using the number of community gardens or area devoted to production. A 2012 survey of community gardens in the US counted more than 9,000 community gardens run by 445 organizations (Lawson 2012). The number of gardens has increased significantly in recent years; the study notes that $39 \%$ of gardens were built in the past five years and that $90 \%$ of organizations reported an increased demand for plots over the past five years. Other studies have attempted to quantify the area devoted to production. A 1999 report notes 111 ha of allotment gardens in Inner London, out of a total of 831 ha serving 30,000 gardeners in the Metropolitan Area (Garnett 2001). A study in Philadelphia counted a total of 226 gardens in Philadelphia totaling 15.4 ha (Vitiello and Nairn 2009). In a recent study, researchers using aerial images and GIS to identify 4,001 home gardens in Chicago, totaling 11.9 ha of productive space, or over half $(57 \%)$ of the city's overall area devoted to agricultural production (Taylor and Lovell 2012). 
Table 1. Common types of urban agriculture

\begin{tabular}{|l|l|l|l|l|l|l|}
\hline $\begin{array}{l}\text { Type of urban } \\
\text { agriculture }\end{array}$ & Organized & Scale of production & $\begin{array}{l}\text { Primary functions or } \\
\text { orientation }\end{array}$ & Management & Labor & $\begin{array}{l}\text { Market } \\
\text { engagement }\end{array}$ \\
\hline Residential & No & Yards & $\begin{array}{l}\text { Production for household } \\
\text { consumption, recreation, } \\
\text { landscaping, occasional sales of } \\
\text { surplus }\end{array}$ & $\begin{array}{l}\text { Individual or } \\
\text { household }\end{array}$ & Self or family \\
\hline Allotment & Yes & Vacant lots, parks & Food production, recreation & $\begin{array}{l}\text { Community garden } \\
\text { program, individual } \\
\text { plot management }\end{array}$ & $\begin{array}{l}\text { Individual community } \\
\text { garden member }\end{array}$ & Occasional \\
\hline Guerrilla & Sometimes & Plants, beds & $\begin{array}{l}\text { valorization and/or transgression } \\
\text { of landscape norms, creation of } \\
\text { "edible landscapes" }\end{array}$ & $\begin{array}{l}\text { Individual or } \\
\text { collective }\end{array}$ & Individual or collective & Rare \\
\hline Collective & Yes & Vacant lots, parks & $\begin{array}{l}\text { Community-building, food } \\
\text { production }\end{array}$ & $\begin{array}{l}\text { Collective, often with } \\
\text { a garden manager }\end{array}$ & Collective members & Occasional \\
\hline $\begin{array}{l}\text { Institutional (eg, } \\
\text { school, prison, } \\
\text { hospitals) }\end{array}$ & Yes & $\begin{array}{l}\text { Yard or other vacant } \\
\text { space, greenhouses }\end{array}$ & $\begin{array}{l}\text { Education, rehabilitation, skills } \\
\text { training }\end{array}$ & $\begin{array}{l}\text { Institution or } \\
\text { contracted } \\
\text { organization }\end{array}$ & $\begin{array}{l}\text { Institutional members } \\
\text { (eg, students, patients, } \\
\text { clients, prisoners), staff, } \\
\text { volunteers }\end{array}$ & Occasional \\
\hline Non-profit & Yes & $\begin{array}{l}\text { Vacant lots, parks, } \\
\text { greenhouses }\end{array}$ & $\begin{array}{l}\text { food security, food justice, } \\
\text { education(foodways, nutrition, } \\
\text { biophysical science) }\end{array}$ & $\begin{array}{l}\text { Non-profit } \\
\text { organization }\end{array}$ & Staff and volunteers & Frequent \\
\hline $\begin{array}{l}\text { Commercial/ } \\
\text { for-profit }\end{array}$ & No & $\begin{array}{l}\text { Large parcels, } \\
\text { rooftops, } \\
\text { greenhouses, yards of } \\
\text { multiple clients }\end{array}$ & $\begin{array}{l}\text { Food production (often through } \\
\text { AFN markets such as CSAs, } \\
\text { farmers markets), edible } \\
\text { landscaping, green infrastructure }\end{array}$ & $\begin{array}{l}\text { Business owner } \\
\text { and/or manager }\end{array}$ & Employees \\
\hline
\end{tabular}


So just how productive are these various forms of urban agriculture and how much do they contribute to overall urban consumption? It is difficult to say. According to a 1992 national census, Australians produced 153,000 metric tons of vegetables per year in their home gardens, an average of about $70 \mathrm{~kg}$ per household (Larder et al. 2012). A Canadian study estimates that gardeners in Montreal produce as much as $70 \%$ of the produce they consume during the 18 -week growing season (Duchemin et al. 2008). Seattle's P-Patch network of 78 community gardens totals 13.5 acres of land under production and provides local food banks with 7 to 10 tons of produce annually, on top of whatever the 4,400 participating gardeners consume for themselves (Seattle Department of Neighborhoods 2012).

As a sampling of studies reveal, however, the variability in productivity both within and across urban agriculture types is great (see Table 2). Given the diversity of urban agriculture types that I differentiate in Table 1, this variability should come as no surprise. In addition to being mediated by environmental factors (such as the length of the growing season, average soil and air temperatures, and incidence of extreme weather or pest outbreaks), productivity also depends on knowledge, labor arrangements, type of management, scale of production, and land tenure. It goes without saying that a school garden tended weekly by schoolchildren is likely to be less productive than commercial production destined for a farmers' market garden or community supported agriculture (CSA) subscription box. Indeed, the function of a particular form of urban agriculture plays a large part in its role in the food system, and therefore, in its role in the broader political economy.

Table 2. Average productivity of urban gardens in selected North American cities

\begin{tabular}{|c|c|c|c|c|c|c|}
\hline $\begin{array}{l}\text { Garden } \\
\text { type }\end{array}$ & City & $\begin{array}{l}\text { Gardens } \\
\text { sampled }\end{array}$ & $\begin{array}{c}\text { Total } \\
\text { productive } \\
\text { area }\end{array}$ & $\begin{array}{c}\text { Total } \\
\text { production }\end{array}$ & $\begin{array}{c}\text { Average } \\
\text { yield }\end{array}$ & Total value \\
\hline & & (n) & (ha) & $(\mathrm{kg})$ & (mt / ha) & (USD) \\
\hline Allotment & Camden, $\mathrm{NJ}^{\mathrm{a}}$ & 48 & 0.57 & 13,987 & 24.69 & $\$ 64,756$ \\
\hline Allotment & Montreal, $\mathrm{QC}^{\mathrm{b}}$ & 1 & 0.02 & 39 & 2.44 & n.d. \\
\hline Allotment & New York. NY ${ }^{c}$ & 67 & 0.69 & 39,245 & 57.04 & $\$ 214,000$ \\
\hline Allotment & 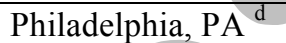 & 226 & 15.38 & 924,032 & 60.09 & $\$ 4,860,364$ \\
\hline Allotment & Trenton, $\mathrm{NJ}^{\mathrm{d}}$ & 29 & 0.57 & 10,291 & 18.16 & $\$ 47,645$ \\
\hline Collective & Montreal, QC ${ }^{b}$ & 35 & 7.03 & 5,904 & 0.84 & n.d. \\
\hline Collective & Portland, $\mathrm{OR}^{\mathrm{e}}$ & 10 & 1.62 & 907 & 0.56 & n.d. \\
\hline Non-profit & Oakland, $\mathrm{CA}^{\mathrm{f}}$ & 9 & 0.59 & 10,433 & 17.66 & n.d. \\
\hline Residential & Montreal, $\mathrm{QC}^{\mathrm{b}}$ & 2 & 0.02 & 114 & 4.75 & n.d. \\
\hline
\end{tabular}

Sources: ${ }^{\mathrm{a}}$ Vitiello et al; ${ }^{\mathrm{b}}$ Duchemin et al 2009; ${ }^{\mathrm{c}}$ Farming Concrete $2010 ;{ }^{\mathrm{d}}$ Vitiello and Nairn; ${ }^{\mathrm{e}}$ unpublished data; ${ }^{\mathrm{f}}$ City Slicker Farms 2011

n.d. = no data

\section{Contradictory interpretations?}

\section{Urban agriculture as radical}

A large and fast-growing body of literature documents the benefits of urban agriculture. Scholars cite urban agriculture's multiple functions and contributions to greener and healthier 
cities, from improving nutritional and psychological health (Wakefield et al. 2007, Freeman et al. 2012) and building community (Bellows et al. 2003, Alaimo et al. 2008, Robinson-O'Brien et al. 2009 ) to reducing the "ecological footprint" by providing green infrastructure (Viljoen 2005, van Veenhuizen 2006) and improving access to fresh and nutritious food in urban food deserts (Kremer and DeLiberty 2011, Metcalf and Widener 2011). In general, scholarship originating in practitioner-oriented fields such as planning, landscape architecture, and public health tends to occupy this end of the spectrum.

As urban agriculture grows in popularity, planning and public health scholars have made a considerable effort to identify opportunities for urban agriculture's growth, measuring urban agriculture's possible contributions to the food system (Mendes et al. 2008, Colasanti and Hamm 2010, MacRae et al. 2010) and identifying best practices for policy and planning (Raja et al. 2008, Hodgson et al. 2011, Wooten and Ackerman 2011). Encouraged by urban agriculture's potential contribution to fresh vegetable production, physical activity, green space, job creation, stormwater retention, greenhouse gas mitigation, neighborhood beautification, "eyes on the street", and community-building, municipal officials across North America are drafting policy to foster urban food production (Lerner 2012, McClintock et al. 2012, Thibert 2012).

Social scientists from a variety of disciplines have also contributed to this constructive discourse, citing urban agriculture's many benefits and emphasizing the oppositional, if not radical, roots of urban agriculture, CSAs, and other AFNs that attempt to re-localize or reconnect production-consumption linkages separated by the industrial agri-food system (Jarosz 2000, Maye et al. 2007, Donald et al. 2010). While scholars debate the extent to which AFNs actually subvert the capitalist logic of the industrial agri-food system, most agree that the rise of AFNs has constituted an attempt to re-embed the agri-food system within the social relations (between producers and consumers) that the industrial system has eroded or stripped away over the last sixty years. Forging "social linkages beyond atomistic market relationships through the production, exchange, processing, and consumption of food" (Kloppenberg et al. 1996, p. 37), many AFNs constitute a form of "civic agriculture" that not only to "meet consumer demands for fresh, safe, and locally produced food, but create jobs, encourage entrepreneurship, and strengthen community identity" by linking production and consumption activities at the local level and offering consumers "real alternatives to the commodities produced, processed, and marketed by large agribusiness firms" (Lyson 2004, p. 2).

One of the central goals of urban agriculture, like AFNs more broadly, has been to reconnect production and consumption while re-embedding both with meaningful social relations. This may take the form of a home gardener who raises chickens to "reconnect" with her food, a "de-alienation" process that reestablishes direct social metabolism of the biophysical environment through manual labor and that reunites the producer with the fruit of this labor (McClintock 2010). It may manifest as a "hired garden" where a farmer grows for a CSA in the customer's front yard (Naylor 2012). Or it may be a guerrilla gardener who plant tomatoes on a sidewalk median in order to engage passersby in food production in unlikely, interstitial spaces (Crane et al. 2012).

Echoing a common theme running through more popular literature on urban agriculture (Winne 2008, Carpenter 2009, Cockrall-King 2012), scholars have also documented the various ways that urban agriculture has strengthened communities, fostering multi-ethnic and multigenerational exchanges of food and agricultural and culinary knowledge (Kurtz 2001, Baker 2004, Saldivar-Tanaka and Krasny 2004, Turner 2011). Scholars have also discussed how such urban agriculture projects can foster civic engagement by creating inclusive spaces for public 
participation and for social learning about food production and consumption (Baker 2004, Levkoe 2006). Such projects "cultivate the political and social skills necessary for effective citizenship, which can have wider transformative effects beyond just growing food" (Travaline and Hunold 2011, 587). Like other forms of "food citizenship" and "food democracy" (Welsh and MacRae 1998, Hassanein 2003), urban garden programs cultivate "urban ecological citizenship" (Travaline and Hunold 2010) through participatory decision-making, community engagement, and environmental stewardship, ultimately empowering participants to take ownership of the food system and the urban environment.

Emphasis on food and agroecological citizenship privileges public over private gain, framing healthy food as a public good and access to it an unalienable right that cannot be left to the logic of the market. The social relations that undergird most AFNs may ultimately pave the way for a more "socially-inclusive form of development" (Donald and Blay-Palmer 2006, p. 1903 ) that both addresses inequity and stands in opposition to the industrial agri-food system. In a study of 18 garden projects in the UK, Milbourne (2011) notes that despite the diversity of forms of urban agriculture, a "desire to address existing injustices - social, environmental or socio-environmental" (13) unified the various projects. As Johnston (Johnston 2008, p. 100) argues, urban agriculture and other AFNs can ultimately serve as a counter-hegemonic tool to reclaim "the commons" from the enclosure of capitalist commodification by "ensur[ing] that access to basic life-goods like food can be met through non-commodity channels, particularly when sufficient purchasing power is lacking." Reclaiming the commons, she explains,

does not necessarily mean that markets and individual consumption styles are eradicated, but it does demand that markets be reembedded in social structures that ensure that nutritious, sustainable food goes not only to those who can afford it but to everyone, and that alternate modes of provisioning - through cooperative provisioning - are equally developed. (ibid., 100-101)

Across the US, many urban agriculture activists organize around a discourse of food justice, a paradigm that draws connections between structural racism and inequitable access to healthy food (Gottlieb and Joshi 2010, Alkon and Agyeman 2011). Under this banner, urban agriculture has served as a rallying point for radical structural critiques and the reclamation of the commons. For many, urban agriculture is now about more than simply gardening. It is a political act, a subversive rejection of the industrial agri-food system. Many urban agriculturalists are demanding rights-based changes to the food system and an increased focus on "entitlements, structural reforms to markets and property regimes, and class-based, redistributive demands for land, water and resources, as captured in the notion of food sovereignty" (HoltGiménez and Shattuck 2011, p. 114).

For some, urban agriculture also may be a means of claiming the "right to the city" (Eizenberg 2012, Shillington 2012), that is, to occupy already-produced urban space for new uses and/or to produce new urban spaces. ${ }^{2}$ Guerrilla gardeners have reclaimed the commons by

\footnotetext{
${ }^{2}$ Lefèbvre (1991) argued that space is best conceptualized as a triad comprised of the following: "material spacethe actual space and its forms and objects; representations of space - the knowledge about space and its production; and lived space - the emotional experience of space and the subjective practices that are attached to space" (Eizenberg 2012, p. 767). The production of space, therefore, involves all three interconnected forms. The right to the city is comprised of the right to participate in decisions related to the production of urban space as well as the right to appropriate already-existing urban space for new uses (Purcell 2002, Shillington 2012).
} 
cultivatin/ig highway medians and vacant lots, an act of transgression of normative conceptions of urban space (Crane et al. 2012). Read from this perspective, even residential urban agriculture can be implicitly —or at times explicitly — radical in its orientation. In a recent survey of 134 urban livestock owners in 49 cities across the US, a majority framed their practice in oppositional relation to the industrial agri-food system. Naylor (2012) explains that residential gardeners often tear up the sod in the front yard in an effort to subvert the hegemony of the American lawn. While Shillington $(2012$, p. 2) examines patio gardens in Managua, her conclusions are equally true of home gardens of the Global North; because "everyday socionatural relations of home also shape broader socio-spatial organization", she argues, "through the practice of urban agriculture, households create particular ecologies that assist in asserting their rights to the city, or more specifically, their right to urban metabolism."

In sum, a substantial body of scholarship accurately positions urban agriculture as oppositional to the industrial agri-food system and the social and environmental ills it externalizes. This literature illustrates the ways in which urban agriculture in its various forms might successfully reembed food production and consumption with meaningful social relations, serve as a battleground for food justice, and claims the right to the city. In doing so, this literature provides urban agriculture proponents with a compelling language and an analytic to both make sense of and to justify their actions. But are these urban agriculturalists unknowingly facilitating the logic of neoliberal restructuring despite their radical intentions?

\section{Garden-variety neoliberalization?}

Neoliberalism is the dominant free market ideology that took hold in the US under Reagan and that has since fueled corporate deregulation and the dismantling of the New Deal social welfare system (Harvey 2005). A set of processes rather than an ideology, neoliberalization has entailed both the "rolling back" the safety net and government oversight, and the "rolling out" of new social and economic relationships that further fuel capitalist accumulation. Examples of roll-out neoliberalization include privatization, marketization, market-friendly reregulation, flanking mechanisms, and shifting discourse to self-sufficiency and personal responsibility (Brenner and Theodore 2002, Brenner et al. 2010, Castree 2010a). As the recent Occupy protests reminded us, the end result of three decades of neoliberalization has been a tremendous concentration of wealth by a small elite at the expense of the wages, rights, and health of the majority and the simultaneous degradation of the physical environment (Harvey 2005, Heynen et al. 2007).

Within this political economic context, many critical scholars are less sanguine about urban agriculture's possibilities, despite their underlying radical intent. Some have argued that the good deeds of organized urban agriculture projects, like other AFNs, actually bolster neoliberalism by providing food to those hit hardest by the roll-back of the welfare state (Allen and Guthman 2006, Guthman 2008, Pudup 2008). As these organizations fill the gaps in the social safety net left by the evisceration of the Keynesian welfare state, some urban agriculture projects employ a neoliberal discourse of entrepreneurialism and self-help that shifts responsibility onto the shoulder of individuals and their communities. While Pudup (2008) acknowledges that earlier community gardening activities were spaces of "social resistance", she argues that contemporary "organized garden projects" are "spaces of neoliberal governmentality, that is, spaces in which gardening puts individuals in charge of their own adjustment(s) to economic restructuring and social dislocation through self-help technologies centered on 
personal contact with nature" (1229). Individual responsibility and choices - to purchase or grow healthy food - only goes so far, however. As Allen (2010) writes, "those with the greatest need often have the least ability to exercise individual choice" precisely because "allocations of choices are shaped by the historical demographics of inequality" (300).

For Pudup and other critics, a focus on individual (re)connection to "where food comes from" and on individual consumer choice (e.g., "eat locally" and "vote with your fork") is implicitly grounded in a neoliberal ideal that "citizenship achieves its most perfect expression through consumer choice in the marketplace" (Pudup 2008, p. 1238), thereby shifting urban consumers away from structural understandings of how such choices are allocated. Organized urban agriculture projects emphasizing self-sufficiency and which situate transformative change within spaces of consumption therefore serve in an anti-politics capacity (Guthman 2007a, Pudup 2008) where the transformation of the food system is relegated to individual choice and individual reengagement with food rather than via collective action.

Similarly, many urban agriculture efforts - non-profit, residential, and institutional initiatives alike - complement their radical critique of an inequitable food system with marketbased solutions, gearing production for sale in farmers market and CSAs. While this may seem a reasonable way to simultaneously distribute fresh food in urban food deserts while building the entrepreneurial skill set of participants, critics argue that this approach perpetuates a neoliberal rationality by locating solutions to social problems within the market rather than the state (HoltGiménez and Wang 2011, Alkon and Mares 2012).

Critics have also shown how AFNs have proliferated as the result of another especially visible roll-out mechanism: the increased dependence on non-profit, voluntary, faith-based, or community-based alternatives in the wake of the roll-back of the Keynesian welfare state (Allen and Guthman 2006, Guthman 2008). These "flanking mechanisms" (Jessop 2002), so-called because they buttress a weakened network of social services, deliver services and entitlements once provided by the government. The patchwork of organizations form a "shadow state" that is inherently uneven in its ability to provide services (Wolch 1990, Lake and Newman 2002, Trudeau 2008). "Through their piecemeal actions," writes Castree, such flanking organizations "do not threaten the neoliberal order or encourage others to seriously challenge it" (Castree 2010a, p. 1744). The increasing reliance on public-private partnerships - often framed as "citizen empowerment"- ultimately reflects the ever-changing priorities of funding organizations and privileges the agendas of those better able to organize and marshal this funding, leaving a highly uneven landscape of social service provisioning.

Following this line of critique, the inability of the patchwork of urban agriculture organizations to fill in the gaps left by state retrenchment - in this case, to guarantee food security - ultimately produces what Lake and Newman (2002) refer to as "differential citizenship" despite noble efforts to feed a hungry population. Only those individuals who have access to the services provided by organizations (because of spatial proximity or to the ability to participate as a volunteer) ultimately tap into the entitlements of citizenship that these organizations provide.

Similarly, efforts to cultivate "urban ecological citizenship" and "food citizenship" as described in the previous section are therefore inherently uneven due to the limited reach of the patchwork of organizations. The food citizenry that arises from their work is a differential one; at one end of the spectrum lies an elite group of citizens who can demand healthy food and sustainable agri-food practices, and at the other end, the majority who will ultimately embody the externalities of the industrial food system and who will remain unequipped with the knowledge and skills necessary to procure food through AFNs. 
This highly uneven terrain of urban agriculture-mediated food provisioning is further shaped by the volatility of funding streams. Urban agriculture organizations frequently compete for the same modest grants and end up fighting for proverbial crumbs. Moreover, these crumbs often define the missions of the organizations, limiting the scale and scope of what they are able to accomplish. The patchwork of non-profit organizations - often referred to by activists as "the non-profit industrial complex" - tasked with stewarding food citizenship must ultimately tailor their programs to tap grant monies dedicated to a particular type of project. If the funding "flavor of the month" happens to be school gardens, then school gardens move to the center of these organizations' activities and discourses. Such material and discursive shifts, in turn, define the movement itself.

Another key concern is that urban agriculture plays a role in the process of gentrification. The "consummate expression of neoliberal urbanism" (Smith 2002, p. 446) gentrification is a process central to carving out new urban spaces for capitalist accumulation (Hackworth 2007). Urban agriculture projects often take root in the vacant "lumpengeography" (Walker 1978) of the inner city, awaiting the next wave of capitalist redevelopment. These neighborhoods, wracked by disinvestment in the wake of capital's spatial fix to the suburbs in the post-war era, are now ground zero for reinvestment under banners of smart growth, walkable neighborhoods, and downtown revitalization (Hackworth 2007, Davidson and Lees 2009). Across North America, these efforts have incorporated urban greening strategies - which include gardens - grounded in an "ecological rationality" that contributes to the increase of property values, while ultimately creating spaces of exclusion (Dooling 2009). Quastel (2009), for example, describes the "ecological gentrification" of Vancouver's Downtown Eastside, where developers offer access to urban garden plots as a way of adding value to new high-end condos. In cities where vacant and cheap land abounds (Detroit and other Rust Belt cities, for example), "land-grabbing" by nascent urban agribusiness has fueled bitter debates over whose interests urban agriculture will ultimately serve (Colasanti et al. 2012). Less inimical, but perhaps equally in need of examination, are the large numbers of well-meaning white activists whose efforts to transform vacant lots into gardens in the name of food security in low-income neighborhoods of color may be inadvertently contribute to the gentrification process (Crouch 2012, Tortorello 2012).

In sum, critical scholarship on agri-food and neoliberalism convincingly reveals the myriad ways in which AFNs, and non-profit civil society organizations more broadly, unintentionally bolster the neoliberalization of cities. Like the scholarship arising from urban agriculture's advocates, these critiques are cogent and insightful. Contrary to the more laudatory interpretations, however, they raise important insights into the limitations of urban agriculture and expose its integuement within broader structural logics.

\section{Coming to terms with contradiction}

How then do we make sense of these apparently contradictory interpretations of urban agriculture? A purely "urban agriculture as radical" perspective overlooks urban agriculture's role in neoliberal urban restructuring. At the same time, "urban agriculture as neoliberal" critiques elide urban agriculture's radical antecedents and its revolutionary possibilities; in taking the latter approach, we risk throwing out the proverbial baby with bathwater sullied by a neoliberal bogeyman.

But to debate whether urban agriculture is neoliberal or radical invokes a false dualism that forces us to answer a question that is too simple. Similarly plotting urban agriculture or other 
AFNs along a neoliberal to radical gradient (Holt-Giménez and Wang 2011, Alkon and Mares 2012) risks essentializing their multiple functions, rationalities, and meanings. Urban agriculture's various forms, I contend, can be radical and neoliberal at once; as Merrifield (2002, p. 5) paraphrasing Marx, writes, "everything is pregnant with its contrary." Indeed, AFNs are "constituted out of multiple, contradictory processes and relations, which they internalize in place and through time" (Jarosz 2008, p. 232). Not only is urban agriculture both radical and neoliberal, I argue that it has to be both. It would not arise as a viable social movement without elements of both, insofar as contradictory processes of capitalism both create opportunities for urban agriculture and impose obstacles to its expansion. Focusing on process - on how and where urban agriculture arises - ultimately offers a better understanding of urban agriculture's various functions and forms and the contradictory tendencies internal to its growth. In the following sections, I attempt to elucidate how urban agriculture arises from these contradictions that often manifest at different scales.

\section{The double-movement and its limits}

To understand the rise of urban agriculture as a socio-spatial process, I first turn to Polanyi (2001), whose conceptualization of capitalism's “double movement" offers a useful starting point for understanding how two contradictory tendencies can exist within a unified whole. Polanyi argued that the disembedding of the economy from the social relations that once defined market exchange has been responsible for much of the violence and unrest of the modern era. Without government regulaton or a moral economy of mutual aid in times of need, the unchecked buying and selling of land, labor, and money — what he terms "fictitious commodities"-leads to social upheaval and environmental degradation. ${ }^{3}$

Robbed of the protective covering of cultural institutions, human beings would perish from the effects of social exposure; they would die as the victims of acute social dislocation through vice, perversion, crime, and starvation. Nature would be reduced to its elements, neighborhoods and landscapes defiled, rivers polluted ... the power to produce food and raw materials destroyed. Finally, the market administration of purchasing power would periodically liquidate business enterprise, for shortages and surfeits of money would prove as disastrous to business as floods and droughts in primitive society. (Polanyi 2001, p. 76)

Polanyi argued that people tend to organize as a "protective counter-movement" in response to the unchecked market exchange of fictitious commodities. This movement, in turn, and can be productive or destructive, peaceful or violent, exclusive or inclusive, from the right or from the left, and forces the restructuring of capital via revolution or reform. The oscillating relationship between market regulation and market excess constitutes the double movement. As noted in a vast body of agri-food literature, the rise of the industrial agri-food system in the mid- $20^{\text {th }}$ century and the profit-based commodification of food have systematically unraveled many of

\footnotetext{
${ }^{3}$ Polanyi calls land, labor, and money "fictitious commodities" because they were not actually produced as commodities for sale on the market. Moreover, they possess qualities that can neither be valued nor regulated by the market, which is why their treatment as simple commodities results in social upheaval. The overexploitation of natural resources and concomitant pollution, the outsourcing of jobs in search of lower wages, and the devaluation of currency all reap havoc on society.
} 
these social relations while degrading environmental quality and the public health of farmworker and consumer alike. ${ }^{4}$ To use Polanyi's words, "leaving the fate of soil and people to the market" has been "tantamount to annihilating them" (ibid, 137).

Urban agriculture often arises from within such a counter-movement organized to protect society from the "pernicious effects of a market-controlled economy" (ibid, 80), acting as a buffer against "acute social dislocation" (ibid, 76). In much of the Global South, urban agriculture serves as a coping mechanism to augment household food production when wages are low or non-existent (McClintock 2010, Zezza and Tasciotti 2010). The same was true in the Global North during the era of industrialization, when pigs, chickens, and vegetables were common sights in the yards of most urban factory workers for well into the $20^{\text {th }}$ century (Bassett 1981, Nicolaides 2001, Moore 2006). Government programs have promoted urban gardening in the US at various moments in history as a means of quelling the unrest of the unemployed and hungry, notably during the two World Wars and the economic crises of the 1890s, 1930s, and 1970s (Bassett 1981, Bentley 1998, Lawson 2005).

Organized urban agriculture projects serving as flanking mechanisms to mitigate food insecurity are, in many ways, contemporary extensions of this history. To the extent that they do not challenge the underlying logic of the industrial agri-food system, they remain, in effect, reformist responses to the externalities of industrial agriculture, "more of a fine-tuning of the neoliberal project rather than a substantive change of direction" (Holt-Giménez and Shattuck 2011, p. 123). Efforts to quell urban unrest and prevent food riots could therefore be seen as undermining radical change rather than underwriting it. For this reason, some critics might see urban agriculture initiatives, despite their oppositional origins or intentions, as more "Pollyannian" than "Polanyian" (Guthman 2007b). Rather than resisting an unrestrained market, they may be naively implicit in certain processes of neoliberalization: by serving as a flanking institution for the shadow state, contributing to neoliberal subject formation by emphasizing personal responsibility, or by advocating market-and consumption-based solutions (HoltGiménez and Wang 2011, Alkon and Mares 2012). As such, they fail to mount a real challenge to the industrial agri-food system despite espousing the language of food systems change.

Following Polanyi's logic, this should come as no surprise. A protective countermovement more often results in reform via regulation or programmatic tweaking than in complete restructuring. Castree (2010b, p. 1738) reminds us that "Polanyi was ultimately far less sanguine than Marx about the possibility for crises (of capital, the state, working people, of resource availability, andor within civil society) leading to structural change." But even if urban agriculture programs fail to effect structural change and ultimately underwrite neoliberalization, they nevertheless buffer society against market excess and failure; indeed, they wouldn't arise if they did not serve this function.

Polanyi's double movement therefore provides a good starting point for understanding the dialectical relationship between market forces and social reform or revolution. Urban agriculture has clearly arisen at times within the context of a Polanyian counter-movement to ward off the negative environmental and social impacts of an unregulated market (e.g., low wages, unhealthy food, environmental pollution). As one Oakland activist observes, without food security, "you're going to have more thieving, more people are going be stealing from stores, robbing people because they don't have no money... Not so they can buy drugs, but so they can

\footnotetext{
${ }^{4}$ A discussion of the social and environmental impacts of the industrial agri-food system is outside of the scope of this paper and has been well documented in a variety of recent popular books (Schlosser 2005, Pollan 2006, Patel 2008).
} 
buy a sandwich. So food production needs to ramp up. More local farms, not just in the outlying areas, but right here in the city, people growing, knowing how to grow" (interview, 16 March 2009).

However, a purely Polanyian analysis does not fully appreciate the level to which capitalist hegemonic tendencies are internal to "society" and the social organizations that constitute it (government, non-profits, community organizations, among others). Rather than viewing the market and the state or society in opposition, we must take cues from Gramsci to recognize the presence of countervailing regulatory and neoliberal tendencies within social groups and governmental institutions (Burawoy 2003, Ekers et al. 2009, Loftus 2012), and to understand "under what conditions and in what form state and society will hold up the market juggernaut, throw up barriers to or rush headlong away from the commodification of land, labor, and money" (Burawoy 2003, p. 244).

Examples abound of such countervailing tendencies. Historically, government, industry, and civil society alike have used gardening programs as a way to cultivate somewhat contradictory values of citizenship through community engagement and bootstrap individualism among workers, immigrants, and schoolchildren (Bassett 1981, Bentley 1998, Lawson 2005). During the 1970s, the USDA established Master Gardener programs in 1972 and the Urban Garden Program in 1976. The latter program provided horticultural training and nutritional assistance to as many as 300,000 low-income families until the program was slashed following budget cuts in 1994 (Reynolds 2011). When rising land values in the 1980s and 1990s brought gardeners into conflict with landowners (often the municipalities themselves) eager to sell to developers, many of these publicly funded and trained gardeners rose up in opposition to development (Schmelzkopf 1995, Staeheli et al. 2002, Smith and Kurtz 2003). Similarly, the rise of the food justice movement can be traced in part to the proliferation of urban agriculture nonprofits funded by Community Food Security Grants under the 1997 Farm Bill (Gottlieb and Joshi 2010, McClintock 2011a).

Today, a variety of new policies in cities across North America have cropped up to foster urban food production: new zoning ordinances to allow urban residents to raise chickens and bees; new easements to allow construction of greenhouses on rooves and in front yards; new permits to allow home gardeners in residential areas to sell produce grown in their yards; tax incentives to encourage landowners to cultivate fallow land. Municipal ordinances supporting urban agriculture have recently passed in a number of cities, including Seattle (Lerner 2012), San Francisco (Terrazas 2011), Cleveland (Gillespie 2010), Minneapolis (Boros 2012), and Boise (Webb 2012) among others. While some scholars have classified such municipal food policy efforts as neoliberal or reformist because they tend to focus on clearing regulatory obstacles in order to foster urban agricultural entrepreneurialism (Holt-Giménez and Wang 2011, Alkon and Mares 2012), I contend that they simultaneously represent a progressive, if not radical, return of the means of production to urban residents, upending decades-old zoning laws that stigmatized and ultimately restricted urban food production.

\section{Scaling and spatializing urban agriculture's value(s)}

As I attempt to illustrate in Figure 1, such contradictory processes often operate at different scales, making it difficult to consider in tandem. A macro-scale critique may therefore seem irrelevant when considering street level concerns. Furthermore, these processes do not necessarily undermine one another; rather, they exist in dialectical tension. For example, urban 
agriculture on a household and local level may serve as a subversive food production strategy, allowing people to operate outside of the market logic of the industrial agri-food system to varying extents, given time and energy. Activists seeking to reclaim the commons may take over a vacant lot in a radical move to subvert its exchange value with new use values, such as community and the provisioning of food. At the same time, at a macro-level, subsistence food production - mostly by female members of the household - has historically subsidized the cost of capitalist production; because workers grow some of their own food, they can devote less of their income to purchasing food (Bassett 1981, Berry 1993, McClintock 2010). While the contribution to overall consumption may be appear minimal, savings of even a hundred dollars can be significant for a low-income family. But by shifting as the costs of reproduction back into the sphere of the family, wages can remain lower, resulting in greater extraction of surplus value (higher profits) for capitalists (Harvey 2007, pp. 162, 232).

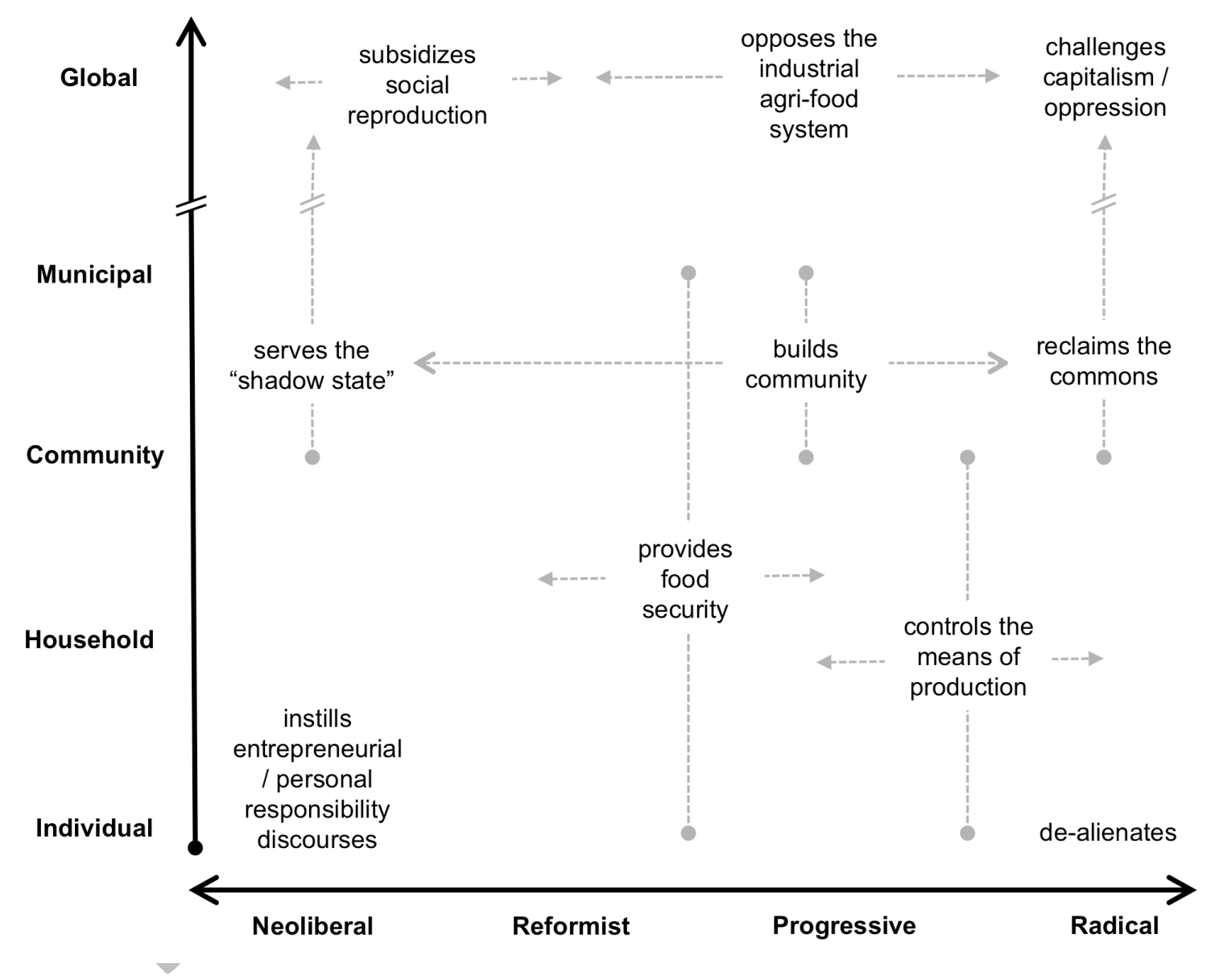

Figure 1. Urban agriculture's multiscalar (and often contradictory) processes. These processes are plotted at various levels of political economic organization (y-axis), ranging from the individual to global, and along a neoliberalradical gradient (x-axis). Dotted lines indicate that processes occur across levels and at multiple scales.

To better make sense of the origins of such contradictions, it is useful to also consider urban agriculture as a spatial process. Where urban agriculture is able to take root depends on a number of political economic factors. In most cases, urban agriculture forms part of the 
"consumption fund" that contributes to the social reproduction of labor (Harvey 2007, pp. 229238). ${ }^{5}$ That is, it contributes to the maintenance of everyday life by providing the gardener and his or her family with food, but also by contributing some level of emotional, spiritual, and/or intellectual fulfillment, necessary for social reproduction. However, unlike other forms of urban nature that form part of the consumption fund, such as lakes, parks, and trees (cf Heynen and Perkins 2005, Perkins 2006), urban gardens often arise in the interstitial spaces and lumpengeographies of the urban landscape when a neighborhood becomes devalued, with devaluation manifest as unemployment, food insecurity, falling land values, and the dilapidation of fixed capital or the built environment. Home gardens notwithstanding, urban agriculture's physical location is often largely a function of land value. Collective, guerrilla, and community gardeners, non-profit and commercial urban agriculturalists alike cultivate opportunistically on land left vacant by the retreat of capital (as in the case of devalued neighborhoods following disinvestment) and by capitalist speculation (as in the case where parcels are bought by land speculators hoping to sell to developers when markets are at their peak). At these times, a vacant parcel's multiple use values - as a site of food production and social interaction - exceed its exchange value on the market.

These same processes of uneven development also create obstacles to urban agriculture's expansion, thereby undermining its long-term stability. When land values increase due to a housing bubble, to the arrival of gentrifiers, or to redevelopment initiatives, the vacant parcel's use values are trumped by its rising exchange value. At these moments, gardens are viewed as hindrances to development, taking up valuable space when markets are booming (cf Schmelzkopf 2002, Staeheli et al. 2002, Smith and Kurtz 2003). Capitalism's cycles of booms and busts - markers of its internal tendencies towards crisis (Harvey 2007) - therefore both enable and constrain urban agriculture's possibilities. These booms and busts do not affect all parts of a city equally; uneven patterns of development are mediated by a variety of factors (e.g., housing policies, taxation, zoning, and bond-ratings), all of which channel flows of residential and industrial capital in and out of particular parts of a city and determine what activities are allowed in particular areas (cf Hackworth 2007, Harvey 2007, Smith 2008).

Urban agriculture therefore represents the simultaneous outgrowth from and reaction to crises of capital. This is apparent when observing its rise as part of a protective countermovement as well as its opportunistic expansion onto land devalued due to the cycle of market booms and busts. Due to this dialectic, urban agriculture is unable to truly derail the industrial agri-food system or the neoliberal logic of contemporary urban political economies. Rather than "sowing the seeds of its own demise," capitalism instead "creates an active society or civil society that contains but does not end tendencies toward crisis and contradiction" (Burawoy 2003, p. 213). This internal contradiction lies at the root of the debate over urban agriculture's radical or neoliberal nature. Categorizing urban agriculture as solely neoliberal or radical obscures these internal contradictions.

\section{Multiple meanings: Examples from Oakland}

As a result of these manifold processes operating at different scales, urban agriculture serves different, sometimes contradictory, functions for different actors and institutions. What

\footnotetext{
${ }^{5}$ Harvey (2007) describes how overaccumulation of surplus value is absorbed by investment in the built environment and the expansion of the consumption fund (235-238); market bubbles result in housing booms and the expansion of infrastructure, as well as the building of parks and other forms of urban nature for consumption.
} 
may be a means of subverting the industrial agri-food system for some is a way to attract development capital to a "transitional" neighborhood or make up up for municipal budget shortfalls in the eyes of others.becomes a practice imbued with multiple meanings and blossoms in spaces where "urban residents construct and reinterpret over time the character and meaning of both urban garden and urban community" (Kurtz 2001, p. 668). Focusing on only one of these meanings obviously leaves us with an incomplete understanding of urban agriculture and hobbles us with the assumptions of its limits and capabilities that we ascribe to a particular meaning or interpretation. Blomley (2004) warns us to "not take the politics of neo-liberalism at face value. Even neo-liberalism can contain forms of neo-socialism" (637), which may simply be rendered invisible by neoliberal categories. Examining a gardening initiative in Canada's poorest neighborhood, on a public right of way on Atlantic Street,in Vancouver's Downtown Eastside, he writes, "Although initiated by one individual, public gardening created overlapping and multiple claims that were both individual and collective. Put another way, if the ghost of John Locke haunted Atlantic Street, so did Gerard Winstanley and the seventeenth century Diggers of radical England" (633). In the same way, "articulated relationships to food cannot possibly be one thing - whether 'bad' or 'good', 'neoliberal' or 'anti-capitalist', 'junky' or 'healthy'” (Hayes-Conroy 2011, p. 74).

As such, even if urban agriculture initiatives emphasize individual connection to food production, preparation, consumption, and health (Pudup 2008), producing neoliberal subjectivities is not necessarily the endgame. Projects organized around urban agricultural activities that may be categorized as neoliberal may also actually serve as important rallying grounds for activists. While organized garden projects may employ the discourse of "healthy choices" and "reconnecting with nature", many of them do so simply to access funding, utilizing the language of a particular request for proposals. What may appear as the production of neoliberal subjectivity may really just be a case of "playing the game" in order to marshal the material resources necessary to create a place where critical perspectives can indeed be fostered, "a politicizing space" where participants are able to "develop new suspicions and misgivings towards broader, corporate structures, and perhaps even new sentiments of entitlement towards government-run food programs" (Hayes-Conroy 2011, p. 83).

My own observations of urban agriculture program facilitators and participants in multiple organizations in Oakland support this conclusion. A discourse of personal responsibility did permeate many of their activities and discussions. But while this could be easily construed as cultivation of neoliberal subjectivity, such discourse in no way supplanted a critique of structural inequalities. On the contrary, Oakland's urban agriculture movement has, in many ways, evolved around a discourse of challenging such structural inequalities. As I have discussed in detail elsewhere (McClintock 2011b), a history of racialized disinvestment from the city's flatlands at various periods during the $20^{\text {th }}$ century created a bifurcated geography of affluence and poverty, whites and people of color, food access and food insecurity. Inspired by a long history of radical social and environmental justice activism dating back to the Black Panthers in the 1960s, urban agriculture in Oakland is often framed in terms of food justice. For many, urban agriculture is a genuine political act, a "metaphoric condensation of the global opposition against Them, those in power, so that the protest is no longer just about the demand, but the universal dimension that resonates in that particular demand" (Žižek in Swyngedouw 2007, p. 23). For many Oakland activitsts, a produce stand that asks those who can afford it to subsidize free produce for those who cannot is about a universal dimension of fairness and redistribution, and community cultivation of the lawn of an abandoned public building or unmaintained park is a call for right to 
the city and the reclamation of the commons.

But the success of these actions reveals the contradictory neoliberal flanking functions visible at a more macro-scale. With limited funding for staff salaries, most urban agriculture organizations in Oakland rely largely on volunteers and interns; unpaid volunteers for City Slicker Farms clocked in more than 1,600 hours in 2011 alone (City Slicker Farms 2012). Volunteer labor is a critical component of neoliberal governance of urban green space, subsidizing cutbacks to state-sponsored services justified via discourses of community participation, personal responsibility, and environmental citizenship (Perkins 2009, Rosol 2011). In the same light, the modest budgets of these organizations are largely tied to grant funding, both public and private. City Slicker Farms, for example, relies on foundation money for at least half of the annual budget (see Table 3). Funding sources guide the activities of urban agriculture organizations to a certain extent. For example, most organizations in Oakland at some point tapped in to a wave of funding dedicated to the development of school gardens a directed significant energy to garden-based education programs for schoolchildren.

Table 3. Funding sources for an urban agriculture non-profit in Oakland, California

\begin{tabular}{|c|c|r|r|r|r|r|r|c|}
\hline \multirow{2}{*}{ Year } & \multirow{2}{*}{$\begin{array}{c}\text { Total } \\
\text { budget }\end{array}$} & \multicolumn{2}{|c|}{ Donations } & \multicolumn{2}{c|}{ Foundations } & \multicolumn{2}{c|}{ Government } & $\begin{array}{c}\text { Foundation } \\
\text { to gov't } \\
\text { ratio }\end{array}$ \\
\hline 2008 & $\$ 164,075$ & $\$ 6,487$ & $\$ 24,979$ & $\$ 101,000$ & $62 \%$ & $\$ 2,765$ & $2 \%$ & 36.5 \\
\hline 2009 & $\$ 311,743$ & $\$ 33,943$ & $\$ 34,412$ & $\$ 160,770$ & $52 \%$ & $\$ 46,542$ & $15 \%$ & 3.5 \\
\hline 2010 & $\$ 454,053$ & $\$ 10,833$ & $\$ 22,523$ & $\$ 224,230$ & $49 \%$ & $\$ 134,792$ & $30 \%$ & 1.7 \\
\hline 2011 & $\$ 420,733$ & $\$ 23,639$ & $\$ 41,491$ & $\$ 201,800$ & $48 \%$ & $\$ 61,466$ & $15 \%$ & 3.3 \\
\hline
\end{tabular}

Source: City Slicker Farms Annual Reports, 2008 - 2011 (www.cityslickerfarms.org)

However, as the data in Table 3 illustrate, funding sources are volatile and urban agriculture organizations cannot count on a particular funding source for very long. The founder of one of Oakland's pioneering food justice organizations bitterly acknowledged that "there was this honeymoon of four or five years where funders were like, 'Oh these small gardens can achieve sustainability, let's give them seed money.' But that's not happening! So that honeymoon's over, the funding's not going to be there anymore..." (interview, 16 June 2009). Such ebbs and flows of funding have in some cases shaped the urban agriculture landscape by defining where and what kinds of gardens have taken root and for whom. Moreover, this is an uneven process. While school gardens are evenly distributed across the city, most non-profit urban agriculture activities are centered in West Oakland, the city's poorest area, precisely because the structural inequities are most apparent here and the vacant lots most numerous. But as a result of funding flows, West Oakland is better served by the food justice movement than most of East Oakland, where socioeconomic conditions and issues of food access are similar (see Figure 2). 


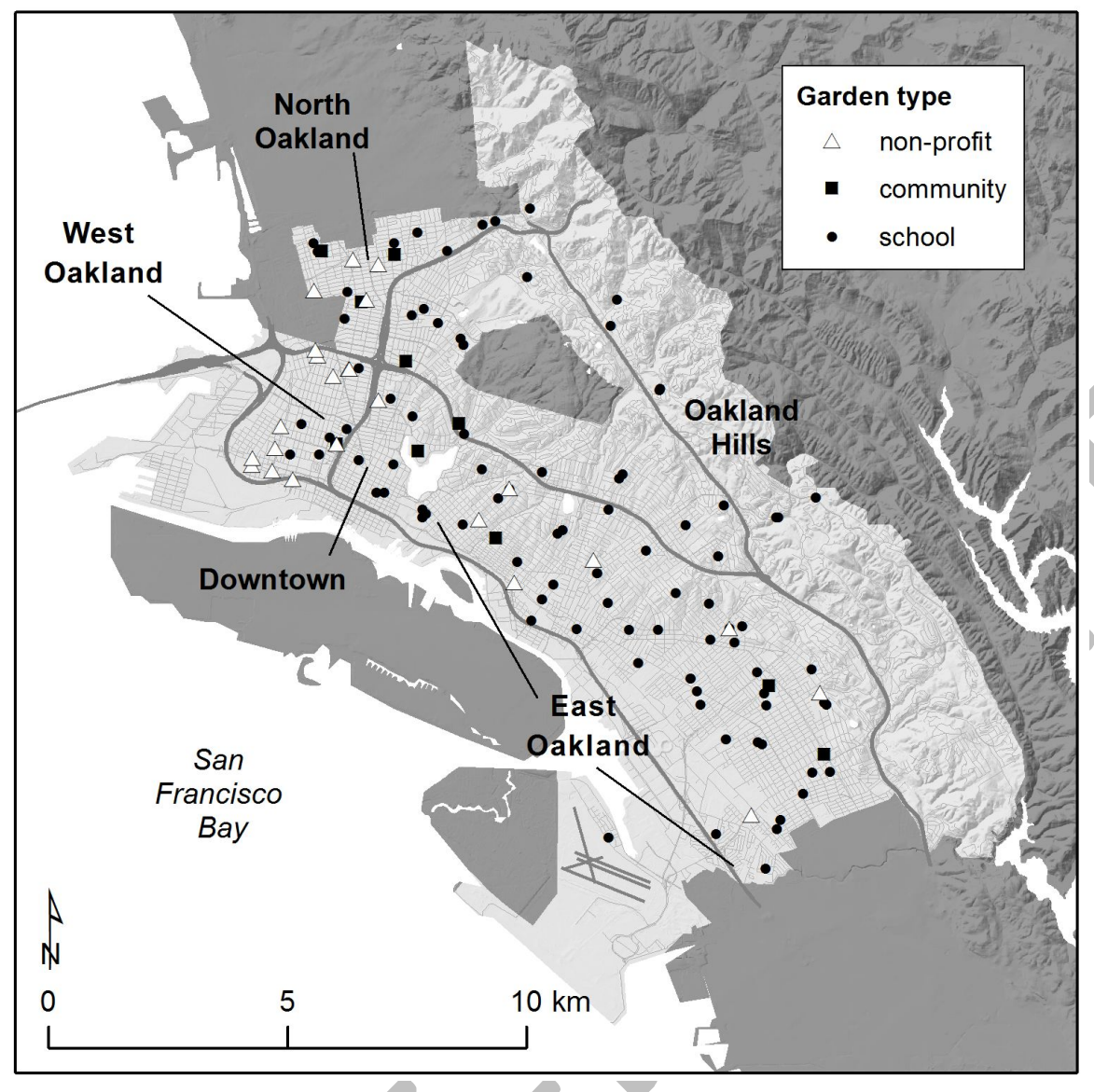

Figure 2. Non-profit, school, and community gardens in Oakland. Note the even distribution of school gardens, but uneven distribution of non-profit gardens. Most urban agriculture organizations are concentrated in West Oakland. In East Oakland, an area that shares many of the same socioeconomic challenges, non-profit urban agriculture gardens are rare.

But this contradiction does not go unnoticed. To the contrary, many urban agriculture activists are acutely aware of this dependent relationship. One East Oakland urban agriculture organization has intentionally remained small in order to not be beholden to funders. A member explained,

It's a small project, but intentionally we haven't really gone after major funding. And it's something we debate, but we also have a critique of the non-profit industrial complex. So even though for most of us, that's our bread, working in non-profits outside of [our own], we have been reluctant to really expand in that type of way (interview, 21 January 2010).

Activists are wary of the burden placed on non-profits to provide food security and other services that they believe the government should provide. Another food justice activist challenged the notion that food justice organizations should even engage in the small-scale education-oriented gardens on which his and other organizations have focused. He explains, 
It actually would make more sense that [small educational gardens] are not run by nonprofits, but that they are in fact part of the city government... I think those of us who are maintaining those size gardens, we're just serving a function that I think city government should serve and fulfill. (interview, 16 June 2009)

It may seem doubtful that a movement so dependent on relatively small flows of public and private funding might effect structural change or create a just alternative to the corporate food regime (with its inherent inequities), much less to sustain itself. Despite these obstacles, however, these organizations have provided material support to community members on shoestring budgets. City Slicker Farms, for example, has produced 31.5 tons of produce over the past decade on 9 gardens totaling 1.5 acres. In 2011 alone, the organization produced 4.4 tons that they distributed to 510 people, $28 \%$ of whom received food for free. The 149 households working under the mentorship of the organization's Backyard Garden Program produced 11.5 tons of food in $2011 ; 90 \%$ of participants reported saving money, $63 \%$ stated that they get more than half of their produce from their garden, and $80 \%$ share or barter the produce they grow with their neighbors (City Slicker Farms 2012). This is not an insignificant contribution to West Oakland's material needs. Rather, it marks the slow, incremental processes of individual dealienation of and community reconnection to the means of production, while simultaneously illustrating both the flanking role of non-profits within the neoliberal shadow state and the subsidization of social reproduction through residential food production.

Perhaps most importantly, examples from Oakland also speak to the vital role that urban agriculture organizations play in consolidating the radical socioecological motivations of individuals into a vocal and visible movement that has been central in putting food justice on the radar of municipal authorities and the public more broadly. Rather than depoliticizing participants, urban agriculture organizations in Oakland - and the growing networks that link them to each other and to backyard farmers in Bay Area and elsewhere- serve as sites of transformative and reflexive politics (DuPuis and Goodman 2005, Levkoe 2011). Such a politics "recogni[zes] conflict as constitutive of the social condition, and the naming of the socioecological spaces that can become" (Swyngedouw 2007, p. 25). The sliding scale produce stand I introduced at the beginning of this paper, along with dozens of other spaces in Oakland, is part of this subversive naming process at the interstitial spaces of the food system and the city, a simultaneous appropriation of urban space and reformulation of productive, distributive, and consumptive practices.

\section{Conclusion}

Urban agriculture has come to represent a radical rejection of an agri-food system that has channeled the externalities of capitalist production into the soil of low-income areas and the bodies of the urban poor. Many urban agriculture initiatives across the Global are reclaiming food production and consumption from the market by re-embedding the agri-food system with social relations by emphasizing equity, sufficiency, and ecological stewardship. At the same time, some of these programs are simply filling the gaps left by neoliberal state retrenchment; they stave off hunger, but may also stave off more political forms of activism necessary to radically reconfigure society. Urban agriculture is not simply radical or neoliberal, but both, operating at multiple scales. 
It is therefore critical to move beyond this dualism. Existing critiques of urban agriculture's neoliberal nature can be counterproductive, amounting to throwing out the baby with the bathwater while failing to address the pressing needs on the ground needs or offer insights into how to overcome contradictions. At the same time, Panglossian assertions of urban agriculture's infinite ability to steward green jobs, food security, healthy eating, and greenhouse gas mitigation will ultimately prove disappointing. Ultimately, identifying and understanding these different and contradictory processes requires analysis at multiple levels - individual, organizational, neighborhood, city, regional, national, global — across several time periods to capture the various spatial and temporal scales at which these processes operate.

Such an analysis also shows that systemic change will certainly not arise from the work of a sparse smattering urban agriculture projects. Rather, as Johnston (2008, p. 101) reminds us, a reclamation of the agri-food commons will consist of "a long-term incremental process of reclaiming social life from an excessive reliance on market logic." A shift in the dominant paradigm surrounding the food system is apparent, as the connections between food, city planning, and public health are discussed in tandem. As urban agriculture becomes increasingly institutionalized and recognized by the mainstream, it may appear more reformist than radical, but nevertheless represents a paradigmatic shift. The extent to which new municipal ordinances supporting the expansion of urban agriculture coalesce and evolve into a robust framework of incentives and regulation that truly challenges the industrial agri-food system remains to be seen.

To successfully challenge the structural forces that gave rise to urban agriculture movement in the first place ultimately requires embedding urban agriculture within a broader framework of justice and structural change. Urban agriculture alone cannot usher in food justice. Food justice requires increased entitlements. It requires jobs and living wages, not just a garden or grocery store in every neighborhood. In other words, we are simply asking too much of urban agriculture - to buffer food security, to create jobs, to provide ecosystems services and green space. Rather than an end unto itself, we should instead view urban agriculture as simply one of many means to an end, one of many tools working in concert towards a unified vision of food justice, and of just sustainability, more broadly,. Ultimately, new forms of value must be ascribed to urban agriculture at the policy level in order for it to join other urban land use priorities such as housing, commercial areas, roads and other infrastructure. Only if the production of fresh and healthy food is viewed as a public good — and access to it a right — rather than simply a commodity made available via the logic of the market, will cities set aside spaces for agriculture in dense urban areas. In short, use value must be privileged over exchange value if urban agriculture is to scale up in any significant way.

The expansion of urban agriculture is a complex process that is continually evolving. And as interest in urban agriculture grows, it will continue to be a fraught and messy process. Integrating urban agriculture into broader, multiscalar discussions of political economic structure, redistributive equity, or just sustainability will not make this any less complex an endeavor, but is a necessary first step in envisioning a more just food system. With time, such an approach may remain subversive, but interstitial no longer.

\section{Acknowledgements}

Thanks to Ryan Galt, Leslie Gray, and Patrick Hurley for organizing the "Interstitial and Subversive Food Spaces" sessions at the 2011 Annual Meetings of the Association of American Geographers in Seattle where the ideas for this paper first took a (somewhat) concrete and 
coherent form. My sincere gratitude also goes to Rachel Brahinsky, Sandy Brown, John Lindenbaum, Seth Lunine, Nathan Sayre, and two anonymous reviewers for their constructive comments on earlier drafts of this paper.

\section{References}

Agyeman, J., 2005. Sustainable Communities And The Challenge Of Environmental Justice. New York: NYU Press.

Alaimo, K., Packnett, E., Miles, R.A., and Kruger, D.J., 2008. Fruit and vegetable intake among urban community gardeners. Journal of Nutrition Education and Behavior, 40 (2), 94-101.

Alkon, A.H. and Agyeman, J., eds., 2011. Cultivating Food Justice: Race, Class, and Sustainability. Cambridge: MIT Press.

Alkon, A.H. and Mares, T., 2012. Food sovereignty in US food movements: radical visions and neoliberal constraints. Agriculture and Human Values, 29 (3), 347-359.

Allen, P., 2010. Realizing justice in local food systems. Cambridge Journal of Regions, Economy and Society, 3 (2), 295-308.

Allen, P., FitzSimmons, M., Goodman, M., and Warner, K., 2003. Shifting plates in the agrifood landscape: the tectonics of alternative agrifood initiatives in California. Journal of Rural Studies, 19, 61-75.

Allen, P. and Guthman, J., 2006. From "old school" to "farm-to-school": Neoliberalization from the ground up. Agriculture and Human Values, 23 (4), 401-415.

Baker, L.E., 2004. Tending cultural landscapes and food citizenship in Toronto's community gardens. Geographical Review, 94 (3), 305-325.

Bassett, T.J., 1981. Reaping on the Margins: A Century of Community Gardening in America. Landscape, 25 (2), 18.

Bellows, A.C., Brown, K., and Smit, J., 2003. Health Benefits of Urban Agriculture. Community Food Security Coalition.

Bentley, A., 1998. Eating for Victory: Food Rationing and the Politics of Domesticity. Urbana: University of Illinois Press.

Berry, S., 1993. No Condition is Permanent: The Social Dynamics of Agrarian Change in Sub-Saharan Africa. Madison: University of Wisconsin Press.

Blomley, N., 2004. Un-real Estate: Proprietary Space and Public Gardening. Antipode, 36 (4), 614-641.

Boros, K., 2012. Expanded "urban agriculture" policy blossoming in Minneapolis. MinnPost, 26 Mar.

Brenner, N., Peck, J., and Theodore, N., 2010. Variegated neoliberalism: geographies, modalities, pathways. Global Networks, 10 (2), 182-222.

Brenner, N. and Theodore, N., 2002. Cities and the Geographies of "Actually Existing Neoliberalism." Antipode, 34 (3), 349-379.

Burawoy, M., 2003. For a Sociological Marxism: The Complementary Convergence of Antonio Gramsci and Karl Polanyi. Politics \& Society, 31, 193-261.

Carpenter, N., 2009. Farm City: The Education of an Urban Farmer. New York: Penguin Press.

Castree, N., 2010a. Neoliberalism and the biophysical environment 1: What "Neoliberalism" is, and what difference nature makes to it. Geography Compass, 4 (12), 1725-1733.

Castree, N., 2010b. Neoliberalism and the Biophysical Environment 2: Theorising the Neoliberalisation of Nature. Geography Compass, 4 (12), 1734-1746.

City Farmer, 2002. 44\% of Vancouver Households Grow Food says City Farmer [online]. Available from: http://cityfarmer.org/44percent.html\#44percent.

City Slicker Farms, 2012. Annual Report 2011. Oakland, CA.

Cockrall-King, J., 2012. Food and the City: Urban Agriculture and the New Food Revolution. Amherst, NY: Prometheus Books.

Colasanti, K. and Hamm, M., 2010. Assssing the local food supply capacity of Detroit, Michigan. Journal of Agriculture, Food Systems, and Community Development, 1 (2), doi:10.5304/jafscd.2010.012.002.

Colasanti, K., Hamm, M., and Litjens, C., 2012. The City as an "Agricultural Powerhouse"? Perspectives on Expanding Urban Agriculture from Detroit, Michigan. Urban Geography, 33 (3), 348-369.

Crane, A., Viswanathan, L., and Whitelaw, G., 2012. Sustainability through intervention: a case study of guerrilla gardening in Kingston, Ontario. Local Environment, doi:10.1080/13549839.2012.716413.

Crouch, P., 2012. Evolution or gentrification: Do urban farms lead to higher rents? Grist. 
Davidson, M. and Lees, L., 2009. New-build gentrification: its histories, trajectories, and critical geographies. Population, Space and Place, 16 (5), 395-411.

Donald, B. and Blay-Palmer, A., 2006. The urban creative-food economy: producing food for the urban elite or social inclusion opportunity? Environment and Planning A, 38 (10), 1901-1920.

Donald, B., Gertler, M., Gray, M., and Lobao, L., 2010. Re-Regionalizing the Food System? Cambridge Journal of Regions, Economy and Society, 3 (2), 171-175.

Dooling, S., 2009. Ecological gentrification: A research agenda exploring justice in the city. International Journal of Urban and Regional Research, 33 (3), 621-639.

Duchemin, E., Wegmuller, F., and Legault, A.-M., 2008. Urban agriculture: multi-dimensional tools for social development in poor neighbourhoods. Field Actions Science Reports, 1 (1), 43-52.

DuPuis, E.M. and Goodman, D., 2005. Should we go "home" to eat?: Toward a reflexive politics of localism. Journal of Rural Studies, 21, 359-371.

Eizenberg, E., 2012. Actually Existing Commons: Three Moments of Space of Community Gardens in New York City. Antipode, 44 (3), 764-782.

Ekers, M., Loftus, A., and Mann, G., 2009. Gramsci Lives! Geoforum, 40 (3), 287-291.

Freeman, C., Dickinson, K.J.M., Porter, S., and van Heezik, Y., 2012. "My garden is an expression of me": Exploring householders' relationships with their gardens. Journal of Environmental Psychology, 32 (2), $135-143$.

Garnett, T., 2001. City Case Study: London. In: N. Bakker, M. Dubelling, S. Guendel, U. Sabel Koschella, and H. de Zeeuw, eds. Growing Cities, Growing Food: Urban Agriculture on the Policy Agenda. Leusden: RUAF, 477-500.

Gillespie, M., 2010. New \$1.1 million program to create urban farms in Cleveland's Kinsman neighborhood. The Plain Dealer.

Gottlieb, R. and Joshi, A., 2010. Food Justice. Cambridge: MIT Press.

Guthman, J., 2007a. From the Ground Up: California Organics and the Making of "Yuppie Chow." In: D. Maye, L. Holloway, and M. Kneafsey, eds. Alternative Food Geographies: Representation and Practice. Amsterdam: Elsevier, 241-254.

Guthman, J., 2007b. The Polanyian Way? Voluntary Food Labels as Neoliberal Governance. Antipode, 39 (3), $456-$ 478.

Guthman, J., 2008. Neoliberalism and the making of food politics in California. Geoforum, 39 (3), 1171-1183.

Hackworth, J., 2007. The Neoliberal City: Governance, Ideology, and Development in American Urbanism. Ithaca: Cornell University Press.

Harvey, D., 2005. A Brief History of Neoliberalism. New York: Oxford University Press.

Harvey, D., 2007. The Limits to Capital, New Edition. Updated. Verso.

Hassanein, N., 2003. Practicing food democracy: a pragmatic politics of transformation. Journal of Rural Studies, 19 (1), 77-86.

Hayes-Conroy, J., 2011. School Gardens and “Actually Existing” Neoliberalism. Humboldt Journal of Social Relations, 33 (1/2), 64-96.

Heynen, N., 2006. Justice of eating in the city: The political ecology of urban hunger. In: N. Heynen, M. Kaika, and E. Swyngedouw, eds. In the Nature of Cities: Urban political ecology and the politics of urban metabolism. London: Routledge, 129-142.

Heynen, N., McCarthy, J., Prudham, S., and Robbins, P., 2007. Neoliberal Environments: False promises and unnatural consequences. London: Routledge.

Heynen, N. and Perkins, H., 2005. Scalar dialectics in green: urban private property and the contradictions of the neoliberalization of nature. Capitalism Nature Socialism, 16 (1), 99-113.

Hodgson, K., Caton Campbell, M., and Bailkey, M., 2011. Urban Agriculture: Growing Healthy, Sustainable Places. American Planning Association, Washington.

Holt-Giménez, E. and Shattuck, A., 2011. Food crises, food regimes and food movements: rumblings of reform or tides of transformation? Journal of Peasant Studies, 38 (1), 109-144.

Holt-Giménez, E. and Wang, Y., 2011. Reform or Transformation?: The Pivotal Role of Food Justice in the U.S. Food Movement. Race/Ethnicity: Multidisciplinary Global Contexts, 5 (1), 83-102.

Jarosz, L., 2000. Understanding agri-food networks as social relations. Agriculture and Human Values, 17 (3), 279 283.

Jarosz, L., 2008. The city in the country: Growing alternative food networks in Metropolitan areas. Journal of Rural Studies, 24 (3), 231-244. 
Jessop, B., 2002. Liberalism, Neoliberalism, and Urban Governance: A State-Theoretical Perspective. Antipode, 34 (3), 452-472.

Johnston, J., 2008. Counterhegemony or Bourgeois Piggery? Food Politics and the Case of FoodShare. In: W. Wright and G. Middendorf, eds. The Fight Over Food: Producers, Consumers, and Activists Challenge the Global Food System. University Park: Pennsylvania State University, 93-120.

Kloppenberg, J., Henrickson, J., and Stevenson, G.W., 1996. Coming into the foodshed. Agriculture and Human Values, 13 (3), 33-42.

Kremer, P. and DeLiberty, T.L., 2011. Local food practices and growing potential: Mapping the case of Philadelphia. Applied Geography, 31 (4), 1252-1261.

Kurtz, H.E., 2001. Differentiating multiple meanings of garden and community. Urban Geography, 22 (7), 656-670.

Lake, R.W. and Newman, K., 2002. Differential citizenship in the shadow state. GeoJournal, 58 (2/3), 109-120.

Larder, N., Lyons, K., and Woolcock, G., 2012. Enacting food sovereignty: values and meanings in the act of domestic food production in urban Australia. Local Environment, doi:10.1080/13549839.2012.716409, 121.

Lawson, L.J., 2005. City Bountiful: A Century of Community Gardening. Berkeley: University of California Press.

Lawson, L.J., 2012. 2012 Community Garden Research Survey Preliminary Report. Presented at the Greater and Greener: Re-Imagining Parks for 21st Century Cities, City Parks Alliance, New York.

Lefèbvre, H., 1991. The Production of Space. Oxford: Wiley-Blackwell.

Lerner, S., 2012. Seattle Food Action Plan. City of Seattle Office of Sustainability and Environment.

Levkoe, C.Z., 2006. Learning democracy through food justice movements. Agriculture and Human Values, 23, 8998.

Levkoe, C.Z., 2011. Towards a transformative food politics. Local Environment, 16 (7), 687-705.

Loftus, A., 2012. Everyday Environmentalism: Creating an Urban Political Ecology. Minneapolis: University of Minnesota Press.

Lyson, T.A., 2004. Civic Agriculture: Reconnecting Farm, Food, and Community. Medford, MA: Tufts University Press.

MacRae, R., Gallant, E., Patel, S., Michalak, M., Bunch, M., and Schaffner, S., 2010. Could Toronto provide 10\% of its fresh vegetable requirements from within its own boundaries? Matching consumption requirements with growing spaces. Journal of Agriculture, Food Systems, and Community Development, 1 (2), (doi:10.5304/jafscd.2010.012.008).

Maye, D., Holloway, L., and Kneafsey, M., eds., 2007. Alternative Food Geographies: Representation and Practice. Oxford: Emerald Group Publishing.

McClintock, N., 2010. Why farm the city? Theorizing urban agriculture through a lens of metabolic rift. Cambridge Journal of Regions, Economy and Society, 3 (2), 191-207.

McClintock, N., 2011a. Cultivation, Capital, and Contamination: Urban Agriculture in Oakland, California. Unpublished PhD dissertation. Department of Geography, University of California, Berkeley. Unpublished $\mathrm{PhD}$ dissertation. University of California, Dept. of Geography, Berkeley.

McClintock, N., 2011b. From Industrial Garden to Food Desert: Demarcated Devalution in the Flatlands of Oakland, California. In: A.H. Alkon and J. Agyeman, eds. Cultivating Food Justice: Race, Class, and Sustainability. Cambridge: MIT Press, 89-120.

McClintock, N., Wooten, H., and Brown, A., 2012. Toward a food policy "first step" in Oakland, California: A food policy council's efforts to promote urban agriculture zoning. Journal of Agriculture, Food Systems, and Community Development, 2 (4), 15-42.

Mendes, W., Balmer, K., Kaethler, T., and Rhoads, A., 2008. Using Land Inventories to Plan for Urban Agriculture: Experiences from Portland and Vancouver. Journal of the American Planning Association, 74 (4), 435-449.

Merrifield, A., 2002. Metromarxism: A Marxist Tale of the City. New York: Routledge.

Metcalf, S.S. and Widener, M.J., 2011. Growing Buffalo's capacity for local food: A systems framework for sustainable agriculture. Applied Geography, 31 (4), 1242-1251.

Moore, S., 2006. Forgotten roots of the Green City: Subsistence gardening in Columbus, Ohio, 1900-1940. Urban Geography, 27 (2), 174-192.

National Gardening Association, 2009. The Impact of Home and Community Gardening in America. South Burlington, VT.

Naylor, L., 2012. Hired Gardens and the question of transgression: lawns, food gardens and the business of "alternative" food practice. Cultural Geographies.

Nicolaides, B.M., 2001. The Quest for Independence: Workers in the Suburbs. In: T. Sitton and W. Deverell, eds. Metropolis in the Making: Los Angeles in the 1920s. Berkeley: University of California Press, 77-95. 
Patel, R., 2008. Stuffed and Starved: The Hidden Battle for the World Food System. Brooklyn: Melville House.

Perkins, H., 2006. Manifestations of Contradiction: Lakes within the Production/Consumption Dialectic. Antipode, $128-149$.

Perkins, H., 2009. Out from the (green) shadow? Neoliberal hegemony through the market logic of shared urban environmental governance. Political Geography, 28 (7), 395-405.

Polanyi, K., 2001. The Great Transformation: The Political and Economic Origins of Our Time. Boston: Beacon Press.

Pollan, M., 2006. The Omnivore's Dilemma: A Natural History of Four Meals. New York: The Penguin Press.

Pudup, M., 2008. It takes a garden: Cultivating citizen-subjects in organized garden projects. Geoforum, 39 (3), $1228-1240$.

Purcell, M., 2002. Excavating Lefebvre: The right to the city and its urban politics of the inhabitant. GeoJournal, 58 (2), 99-108.

Quastel, N., 2009. Political ecologies of gentrification. Urban Geography, 30 (7), 694-725.

Raja, S., Born, B., and Russell, J.K., 2008. A Planner's Guide to Community and Regional Food Planning: Transforming Food Environments, Facilitating Healthy Eating. American Planning Association, Washington.

Reynolds, K.A., 2011. Expanding technical assistance for urban agriculture: Best practices for extension services in California and beyond. Journal of Agriculture, Food Systems, and Community Development, 1 (3), doi:10.5304/jafscd.2011.013.013.

Robinson-O'Brien, R., Story, M., and Heim, S., 2009. Impact of Garden-Based Youth Nutrition Intervention Programs: A Review. Journal of the American Dietetic Association, 109 (2), 273-280.

Rosol, M., 2011. Community Volunteering as Neoliberal Strategy? Green Space Production in Berlin. Antipode.

Saldivar-Tanaka, L. and Krasny, M.E., 2004. Culturing community development, neighborhood open space, and civic agriculture: The case of Latino community gardens in New York City. Agriculture and Human Values, $21,399-412$.

Schlosser, E., 2005. Fast Food Nation: The Dark Side of the All-American Meal. New York: Harper Perrenial.

Schmelzkopf, K., 1995. Urban community gardens as contested space. Geographical Review, 85 (3), 364-381.

Schmelzkopf, K., 2002. Incommensurability, land use, and the right to space: Community gardens in New York City. Urban Geography, 23 (4), 323-343.

Seattle Department of Neighborhoods, 2012. P-Patch Community Gardens [online]. Available from: https://www.seattle.gov/neighborhoods/ppatch/ [Accessed5 Nov 2012].

Shillington, L.J., 2012. Right to food, right to the city: Household urban agriculture, and socionatural metabolism in Managua, Nicaragua. Geoforum, doi:10.1016/j.geoforum.2012.02.006.

Smith, C.M. and Kurtz, H.E., 2003. Community Gardens and Politics of Scale in New York City. Geographical Review, 93 (2), 193-212.

Smith, N., 2002. New Globalism, New Urbanism: Gentrification as Global Urban Strategy. Antipode, 34 (3), $427-$ 450.

Smith, N., 2008. Uneven Development: Nature, Capital, and the Production of Space. Athens: University of Georgia Press.

Staeheli, L.A., Mitchell, D., and Gibson, K., 2002. Conflicting rights to the city in New York's community gardens. GeoJournal, 58 (2/3), 197-205.

Swyngedouw, E., 2007. Impossible "Sustainability" and the Postpolitical Condition. In: R. Krueger and D. Gibbs, eds. The Sustainable Development Paradox: Urban Political Economy in the United States and Europe. New York: The Guilford Press, 13-40.

Taylor, J.R. and Lovell, S.T., 2012. Mapping public and private spaces of urban agriculture in Chicago through the analysis of high-resolution aerial images in Google Earth. Landscape and Urban Planning, 108 (1), 57-70.

Terrazas, A., 2011. Urban farming ready to take root with approval from San Francisco. The Examiner.

Thibert, J., 2012. Making Local Planning Work for Urban Agriculture in the North American Context: A View from the Ground. Journal of Planning Education and Research.

Tortorello, M., 2012. Urban Gardens Grow Everything Except Gardeners. The New York Times, 31 Oct.

Travaline, K. and Hunold, C., 2010. Urban agriculture and ecological citizenship in Philadelphia. Local Environment, 15 (6), 581-590.

Trudeau, D., 2008. Towards a relational view of the shadow state. Political Geography, 27 (6), 669-690.

Turner, B., 2011. Embodied connections: sustainability, food systems and community gardens. Local Environment, $16(6), 509-522$. 
van Veenhuizen, R., 2006. Cities Farming for the Future: Urban Agriculture for Green and Productive Cities. Ottawa: IDRC/RUAF.

Viljoen, A., 2005. Continuous Productive Urban Landscapes: Designing Urban Agriculture for Sustainable Cities. Oxford: Elsevier.

Vitiello, D. and Nairn, M., 2009. Community Gardening in Philadelphia: 2008 Harvest Report. University of Pennsylvania Planning and Urban Studies, Philadelphia.

Wakefield, S., Yeudall, F., Taron, C., Reynolds, J., and Skinner, A., 2007. Growing urban health: Community gardening in South-East Toronto. Health Promotion International, 22 (2), 92-101.

Walker, R., 1978. Two Sources of Uneven Development Under Advanced Capitalism: Spatial Differentiation and Capital Mobility. Review of Radical Political Economics, 10 (3), 28-37.

Webb, A., 2012. Boise City Council approves new rules for urban agriculture, but a vote on river jumping will wait. Idaho Statesman, 12 Apr.

Welsh, J. and MacRae, R., 1998. Food Citizenship and Community Food Security: Lessons from Toronto, Canada. Canadian Journal of Development Studies/Revue canadienne d'études du développement, 19 (4), $237-255$.

Winne, M., 2008. Closing the Food Gap: Resetting the Table in the Land of Plenty. Boston: Beacon Press.

Wolch, J., 1990. The shadow state: Government and voluntary sector in transition. New York: Foundation Center.

Wooten, H. and Ackerman, A., 2011. Seeding the City: Land Use Policies to Promote Urban Agriculture. Public Health Law \& Policy / NPLAN., Oakland.

Zezza, A. and Tasciotti, L., 2010. Urban agriculture, poverty, and food security: Empirical evidence from a sample of developing countries. Food Policy, 35, 265-273. 